\title{
Teachers' Sense of Efficacy: A Challenge for Professional Development Toward Teaching Science as Inquiry
}

\author{
Kumudu Seneviratne ${ }^{1 *}$, Junainah Abd Hamid², Ali Khatibi², Ferdous Azam² ${ }^{2}$, Sepali Sudasinghe ${ }^{3}$ \\ ${ }^{1}$ Faculty of Education, University of Colombo, Colombo 3, 00300, Sri Lanka, ${ }^{2}$ Management and Science University, Shah Alam, Selangor, 40 100, \\ Malaysia, ${ }^{3}$ Management and Science University Colombo Learning Centre, Colombo 3, 00300, Sri Lanka
}

*Corresponding Author: kumusene1969@gmail.com

\section{ABSTRACT}

A teacher's receptivity to inquiry-based instruction is varied due to teacher self-efficacy which invariably affected by his or her immediate professional environment. This study examined how professional development (PD) designs affect in-service teachers' efficacy beliefs to teach inquiry science. This investigation had three objectives: (a) Describe teachers' perceived self-efficacy toward inquiry-based science, (b) investigate the nature of PD designs for inquiry-based science, and (c) examine the association among school characteristics, perceived support from PD programs, and teachers' perceived self-efficacy in student engagement in scientific inquiry. Quantitative data using questionnaires were collected from 350 science teachers in state schools of Colombo and Homagama zones in Sri Lanka in 2018. A General Linear Model Univariate analysis using SPSS 21.00 program was used for data analysis. Findings revealed in-service teachers' perceived self-efficacy in student engagement were lower than that of classroom management and instructional strategies (IS) associated with inquiry-based teaching. A notable fact was less use of PD programs with mastery experiences, which allows science teachers authentic experiences of scientific inquiry practices, while PD programs with vicarious sources of efficacy were comparatively higher. It also reported self-reported efficacy in engaging students in scientific inquiry significantly differed according to school type, support from PD programs, teachers' self-efficacy in IS, and classroom management. The results found no statistically significant differences in perceived efficacy in student engagement by education division in which school was situated. The implications and suggestions for future research are also discussed.

KEY WORDS: teacher self-efficacy; student engagement; classroom management; instructional strategies; inquiry-based science; professional development

\section{INTRODUCTION}

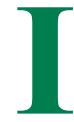
nquiry-based science has long been recommended as an effective teaching approach to improve science learning. Learning and teaching science as inquiry requires not only grasping scientific information but also developing fundamental understandings and abilities to conduct scientific inquiry (NRC, 2000). The publication inquiry and National Science Education Standards (NRC, 2000) emphasizes five essential characteristics of classroom inquiry: (1) Learner engages in scientifically oriented questions; (2) learner gives priority to evidence in responding to questions; (3) learner formulates explanation from evidence in responding to questions; (4) learner connects their explanations in light of alternative explanations, particularly those reflecting scientific understanding; and (5) learner communicates and justifies their proposed explanations. Including all these five characteristics, science educationists have developed an inquiry continuum that classifies classroom inquiry into different levels: (1) Structured inquiry; (2) guided inquiry; (3) student-directed inquiry; and (4) open inquiry or student research inquiry (Liang and Richardson, 2009).

There is no doubt that it requires prepared teachers with adequate knowledge of science content and instructional strategies (IS) of scientific inquiry preferably through handson activities to be able to enact this in the classroom. Thus, professional development (PD) sessions need to aim to provide teachers the same kinds of learning opportunities as their students to experience for themselves the scientific inquiry process (Jeanpierre et al., 2005). Despite this need, most science teachers are not only not sufficiently prepared to teach science in terms of both knowledge of science content and familiarity with inquiry-based science instruction (Kennedy, 1998) but also they are inadequately equipped to meet the learning needs of diverse students (Bryan \& Atwater, 2002). This lack of teacher preparedness may result in confusion in implementation of scientific inquiry in science classrooms (Almuntasheri et al., 2016).

Simultaneously, previous studies have investigated other influential factors specifically for the implementation of inquiry learning; (1) teachers' personal attribute factors (interest, motivation, teaching efficacy, and professional science knowledge); (2) environmental factors (limited time and resources and insufficient external support from the school community); and (3) the interaction of these factors (Choi \& Ramsey, 2009; Lewthwaite, 2006; Ramnarain, 2016). Out of teacher personal attribute factors, low teacher self-efficacy (TSE) has long been a problem, which results in teachers 
being limited in using expository methods rather than inquiry. Based on research studies, teacher performance, in general, is closely associated with their self-efficacy construct (Ahokoski et al., 2017; Appleton \& Kindt, 2002; Holtzberger et al., 2013; Klassen \& Tze, 2014; Rice \& Roychoudhury, 2003). Research has also emphasized the strong relationship between internal teachers' beliefs and values of science and their enactment of inquiry-based teaching (Lotter et al., 2007). In addition, exploitation of self-efficacy as mediating and moderating constituents in manifesting the linkage between the PD activity and the teacher's actual practice of inquiry-based science teaching has been reported in the literature (Ahokoski et al., 2017; Decoito \& Myszkal, 2018; Lotter et al., 2018; Mintz et al., 2013; Sandholtz \& Ringstaff, 2013; Zimmerman et al., 2017). Among the subscales of TSE, previous studies often showed a slightly lower level of self-reported efficacy in student engagement in scientific inquiry teaching (Ahokoski et al., 2017; Roberts et al., 2006; Stripling et al., 2008; Swan et al., 2011; Wolf et al., 2008).

Therefore, this paper is an exploratory and illuminating study into what level in-service science teachers perceive selfefficacy beliefs for inquiry-based science teaching in general, and particularly focusing on student engagement, and how PD designs affect their efficacy beliefs to teach inquiry science in the classroom. This study sought to address three research questions (a) what were the teachers' perceived self-efficacy in teaching scientific inquiry? (b) How science teachers are prepared to teach inquiry-based science? and (c) Are perceived support from science teacher PD programs, teacher efficacy in classroom management (CM) and IS and school characteristics (school type and education division) predictors of teachers' self-efficacy in student engagement toward the enactment of inquiry-based science. The results enable to claim interactions among the multi-faceted PD designs for inquiry science teaching, changes in science teachers' self-efficacy in terms of student engagement, $\mathrm{CM}$, and IS of inquiry-based teaching in line with PD, and school characteristics. The findings would also benefit to identify how PD forms could be effectively tailored to use self-efficacy sources in accordance with teachers' beliefs and actual practices of inquiry-based science in the classroom. This investigation further provides valuable insights for school administrators in assisting their academic staff in scientific inquiry teaching.

\section{LITERATURE REVIEW}

\section{Inquiry-based Science}

Anderson (2002) states that good science teaching and learning have come to be distinctly and increasingly associated with the term inquiry. The generalized conceptions of inquiry teaching and learning which reflect current scholarship on the nature of science (NOS) and in education is evident in science education reform documents (AAAS, 1993; NRC, 1996). According to such conception, inquiry has been distinguished both as a means and ends (Abd-El-Khalick et al., 2001). "Inquiry as means (or inquiry in science) refers to inquiry as an instructional approach intended to help students develop understandings of science content (i.e., content serves as an end or instructional outcome) (p. 398)." "Inquiry as ends (or inquiry about science) refers to inquiry as an instructional outcome: Students learn to do inquiry in the context of science content and develop epistemological understandings about the NOS and the development of scientific knowledge, as well as relevant inquiry skills (e.g., identifying problems, generating research questions, designing and conducting investigations, and formulating, communicating, and defending hypotheses, models, and explanations p. 398)." In this study the latter is taken as teaching scientific inquiry. This study focus was on the teacher's instructional behavior, i.e., how they teach students to do inquiry in the classroom using inquiry skills. Thus, among the diverse conceptions of scientific inquiry in the line of research, the definition proposed by NRC (1996) for scientific inquiry is concerned as the specific instructional task associated with teacher's self-efficacy in this study. Accordingly, in this study, scientific inquiry is referred to as:

Inquiry is a multifaceted activity that involves making observations; posing questions; examining books; and other sources of information to see what is already known; planning investigations; reviewing what is already known in light of experimental evidence; using tools to gather, analyze, and interpret data; proposing answers, explanations, and predictions; and communicating results. Inquiry requires identification of assumptions, use of critical and logical thinking, and consideration of alternative explanations (NRC, 1996).

\section{TSE}

As stated, TSE is associated with teaching scientific inquiry. Albert Bandura (1977) stated teacher efficacy as a type of self-efficacy and defined self-efficacy as "beliefs in one's capabilities to organize and execute the courses of action required to manage prospective situations" (p. 3). On the other hand, Tschannen-Moran et al. (1998) defined teacher efficacy as "the teacher's belief in his or her capability to organize and execute course of action required to successfully accomplish a specific teaching task in a particular context" (p. 22). Guskey (1988) determined that TSE is a good indicator of teacher attitudes toward implementing a new instructional practice or reform. In his study, Guskey found that teachers who are "confident about their teaching abilities" (p. 67) are also the "most receptive to the implementation of new instructional practices" (p. 67).

Tschannen-Moran and Woolfolk (2001) suggest that TSE is a simple idea with significant implications. The authors reported that teachers with high efficacy expend more effort in teaching and show greater persistence in the face of obstacles. In addition, they are more likely to try new instructional approaches in an effort to find better ways of teaching and are more willing to work with students who are experiencing difficulties (Palmer et al., 2015). Based on the previous research, TSE has been found to be correlated with 
teacher performance (Ahokoski et al., 2017; Appleton \& Kindt, 2007; Holtzberger et al., 2013; Klassen \& Tze, 2014; Palmer et al., 2015; Rice \& Roychoudhury, 2003) beliefs about and willingness to improve method of instruction using inquiry (Leonard et al., 2011; Smolleck \& Mongan, 2011). Furthermore, Swars and Dooley, in 2010 stressed highly efficacious teachers attributed their high sense of teaching efficacy to their increased knowledge of teaching strategies, among them inquiry, interactive, and hands-on learning.

The theoretical framework for this study was based on Bandura's social cognitive theory (Bandura, 1986) and the associated theory of self-efficacy (Bandura, 1997). According to Bandura (1997), personal efficacy is one of the most central mechanisms, which has an influence on human behavior. Individuals possess self-beliefs that enable them to exercise a measure of control over their thoughts, feelings, and actions. To analyze the PD programs, which can potentially enhance selfefficacy among in-service teachers, the four efficacy sources proposed by Bandura (1997) were extensively reviewed. The sources that can produce changes in self-efficacy include: (1) Enactive mastery experiences, (2) vicarious experiences, (3) verbal persuasion, and (4) psychological/affective states. Enactive mastery experiences are authentic experiences in which one demonstrates the capability to succeed in the task and considered to be the most powerful source in fostering sense of self-efficacy. Such experiences have been discussed in literature; scientific inquiry projects (Liang \& Richardson, 2009), simulated lessons, and successful participation in science teaching practice (Kenny et al., 2014; Mansfield $\&$ Woods-McConney, 2012). The second source, vicarious experiences occur when seeing or visualizing a person perform a task successfully can enhance observer's belief in his/her capability. The advantages of this source have been stressed; heavy emphasis on hands-on activities, cooperative learning, and discussion (Posnanki, 2007), and modeling both teaching strategies and attitudes that were appropriate in primary teaching (Rice \& Roychoudhury, 2003). The third efficacy source is verbal persuasion, which occurs when significant others express one's capabilities. Physiological/affective state refers to one's reaction to stress, fatigue, and mood. Verbal persuasion has been reported to occur through the professor's role as a mentor and his/her comments to the class, and students have been helped to deal with their stress and anxiety about science learning by having extensive classroom discourse (Gunning \& Menash, 2011). The third and fourth efficacy sources are considered to be less influential (Bandura, 1997).

\section{Sense of Efficacy Beliefs and Teacher Education}

The way teachers view science, experience in learning science affect the way in how they implement science in the classroom (Crawford, 2000; Lotter et al., 2007). Hence, teacher training has been identified as a key element in enabling teachers to implement reform-oriented practices (Lee et al., 2004), such as inquiry-based science. The emerging literature suggests the importance of the substance of professional activities toward perceived competence to implement inquiry-based science; engaging in authentic scientific investigation (Capps \& Crawford, 2013); stimulating active learning, and providing a practical guide (Voet \& De Wever, 2017). Similarly, the impact of professional activities on teachers' inquiry-based learning (IBL) related beliefs also has been emphasized. However, Silm et al. (2017) argued the training programs aimed at inquiry approach and improving teachers' knowledge and attitudes toward it is lacking. The in-service teacher education model has been transformed from predominantly used cascade model to school based teacher development (SBTD) model in Sri Lanka (Gunawardane, 2011). Yet, the issue of not organizing such programs on teachers' needs related to their classroom practice in general (Gunawardane, 2011), in particular in science (McCaul, 2007; Seneviratne, 2009) is still prevailing. Gunawardane (2011) also elaborated about weaknesses in teacher education system (1) delay in changing over to the innovative methods of teaching-learning, and (2) the delay in transforming from the earlier emphasis of theory based teacher education to a more practice based teacher training. However, there is research evidence on positive effects of specially designed teacher education courses, particularly using Bandura's self- efficacy sources (Erticanto et al., 2017; Lee \& Shea, 2016; Palmer et al, 2015; Swan et al., 2011).

\section{RESEARCH METHODOLOGY}

\section{Objectives}

The purpose of the current cross-sectional study was to determine the impact PD programs on teachers' perceived self-efficacy, which in turn affect the actual practice of inquiry-based science teaching in the classroom. The following research objectives guided the study:

1. Determine the teachers' perceived self-efficacy in teaching scientific inquiry in terms of student engagement, CM, and IS

2. Investigate the level of preparation of science teachers for inquiry-based science teaching through different PD programs

3. Examine if perceived support from science teacher PD programs, teacher efficacy in CM and IS and school characteristics (school type and education division) are predictors of teachers' self-efficacy in student engagement toward enactment of inquiry-based science.

\section{Participants}

A stratified random sample of 350 science teachers participated in this study. The inservice science teachers comprised 61 males $(17.4 \%)$ and 289 females $(82.6 \%)$ from state schools in the Colombo and Homagama education zones of the Colombo district in Sri Lanka. By education level, the sample represented 111-degree holders (31.7\%) and 239 were non-degree holders which are of $68.3 \%$. With regard to area of certification of the respondents, $150(42.9 \%)$ teachers with National Diploma in Education, 138 (39.4\%) teachers with postgraduate qualifications, and $62(17.7 \%)$ represented without professional qualification to teach science in the sample. More than half of the science teachers (52.6\%) belong 
to less experienced category having $<10$ years of full-time teaching the science instruction had in the classroom. The percent of experienced teachers with more than 10 years of teaching experience in science was $47.4 \%$. The sample represented $202(57.7 \%)$ teachers from Colombo zone, while the percentage of teachers from Homagama zone was $42.3 \%$ (148) with the informed consent.

\section{Instrumentation}

This study utilized a questionnaire, which consisted of three sections: (1) teacher demographics (Q1-Q6), (2) TSE (Q7Q26), and (3) PD programs (Q27-Q32). The Teachers' Sense of Efficacy Scale (TSES) (Tschannen-Moran \& Woolfolk Hoy, 2001) was adapted to assess the TSE of the science teachers. The instrument asked participants to rate their capabilities; "How much can you." utilizing the following anchored scale: $1=$ Nothing, $3=$ Very Little, $5=$ Some Influence, $7=$ Quite a Bit, and $9=$ A Great Deal. The TSES has been extensively utilized and subjected to factor analysis procedures to assess construct validity (Tschannen-Moran \& Woolfolk Hoy, 2001). The present study utilized the amended long summated rating scale (20 items) consisting of three distinct domains so that efficacy for IS (7 items), efficacy for CM ( 7 items), and efficacy for student engagement (6 items). Section three of the survey instrument contained the statements related to teachers' perceptions of teacher education program with reference to its orientation toward development of TSE as well as mastering skills in teaching scientific inquiry. Elements related to the development of self-efficacy were identified from the empirical research findings as identified in terms of four sources of selfefficacy by Bandura $(1986,1997)$. Similarly, teacher education was also operationalized from the empirically evident indicators in terms of the extent of teacher preparation in mastering skills in teaching scientific inquiry. The empirically evident facts were collectively considered and eight indicators/elements were constructed as measured from the questions (27-34). It consisted two indicators with enactive mastery experiences
(27-28), two indicators with vicarious experiences (30-31), two indicators with verbal persuasion (32-33), and another two indicators in association with psychological arousal source $(30,34)$. Adhering to the ethics such as informed consent and confidentiality, which assured the self-esteem and self-respect of the participants, the pilot study was administered personally just once, over a period of 1 month. Table 2 illustrates the summary of the items under two constructs after the pilot test.

A general linear model (GLM) univariate analysis using SPSS 21.00 program was used for descriptive statistics and association between perceived TSE and perceived level of teacher preparation through PD for inquiry-based science teaching, and effect size was using partial eta squared.

\section{RESULTS}

\section{Teachers' Perceived Self-efficacy in Teaching Scientific Inquiry}

For the 350 science teachers who participated in the survey, the mean perceived overall TSE in teaching scientific inquiry was $7.24 \pm 0.44$, while mean perceived TSE in student engagement (TSESE) in scientific inquiry activities was $6.91 \pm 0.50$. The mean perceived TSECM when students engage in scientific inquiry activities reported $7.56 \pm 0.56$, while that of in IS in relation to the scientific inquiry was $7.34 \pm 0.50$.

\section{Perceived TSESE}

As per the descriptive in Table 3, the lowest perceived TSE in TSESE reported for motivating students who show low interest in scientific inquiry $(6.52 \pm 0.71)$ and for improving understanding of a student who is failing in scientific inquiry $(6.57 \pm 0.72)$. On the other hand, teachers held quite high beliefs in their ability to get their students to believe they can do well in scientific inquiry $(7.07 \pm 0.71)$ and also in helping students value learning through scientific inquiry $(7.27 \pm 0.69)$. The self-reported efficacy in fostering student creativity was

\begin{tabular}{lcc}
\hline Table 1: Descriptive statistics for respondents' profile & & \\
\hline Characteristic & Frequency & Percentage \\
\hline Gender & 61 & 17.4 \\
$\quad$ Male & 289 & 82.6 \\
$\quad$ Female & 111 & 31.7 \\
Education level & 239 & 68.3 \\
$\quad$ Degree holders & & 42.9 \\
$\quad$ Non degree holders & 150 & 39.4 \\
Area of certification & 138 & 17.7 \\
$\quad$ Qualified with Training or National Diploma & 62 & 52.6 \\
$\quad$ Qualified with postgraduate qualifications & & 47.4 \\
$\quad$ Professionally non-qualified & 184 & 57.7 \\
Teaching experience in science & 166 & 42.3 \\
$\quad$ Less experienced (Less than 10 years) & & 202 \\
$\quad$ More experienced (more than 10 years) & 148 & \\
Education Zone & & \\
$\quad$ Colombo & & \\
$\quad$ Homagama &
\end{tabular}


$6.93 \pm 0.69$. The mean score of around 6 suggests that there is, however, low self-efficacy in overall beliefs in student engagement associated with scientific inquiry in science. About $47.7 \%$ of the science teachers held moderate beliefs that they could motivate students who show low interest in scientific inquiry in teaching scientific inquiry. About $52.6 \%$ of respondents believed they could make quite an influence in fostering student creativity (SE5) while the percentage with high belief was $16.9 \%$. With regard to improving understanding of a student who is failing in scientific inquiry (SE6), the percentage with high belief was low (11.1\%).

\section{Perceived TSECM}

Out of the three subscales of self-efficacy, the mean perceived TSECM associated with scientific inquiry in science reported comparatively a higher level, as illustrated in Table 3.

As shown in Table 2, the mean score of around 7 suggested that there was high self-reported efficacy in overall beliefs in CM associated with scientific inquiry in science. More than $50 \%$ of the participating science teachers reported quite a high belief that they could motivate students who showed low interest in scientific inquiry in teaching scientific inquiry.

Table 2: Summary of the items under two constructs after the pilot test

\begin{tabular}{|c|c|c|c|c|}
\hline \multirow[t]{2}{*}{ Construct } & \multirow[t]{2}{*}{ Dimensions } & \multicolumn{2}{|c|}{ No. of items } & \multirow[t]{2}{*}{ Cronbach's $\alpha$} \\
\hline & & Initial & Final & \\
\hline Support from teacher education program & & 8 & 6 & 0.722 \\
\hline \multirow[t]{4}{*}{ Teacher self-efficacy } & & 24 & 20 & 0.901 \\
\hline & Teacher self-efficacy student engagement & 8 & 6 & 0.809 \\
\hline & Efficacy classroom management & 8 & 7 & 0.870 \\
\hline & Efficacy instructional strategies & 8 & 7 & 0.825 \\
\hline
\end{tabular}

Table 3: Descriptive statistics for each factor under three sub scales of teacher self-efficacy

\begin{tabular}{|c|c|c|c|}
\hline Components of teaches self-efficacy & $\mathbf{n}$ & Factors & Mean \pm standard deviation (1-9) \\
\hline \multirow[t]{6}{*}{ Student engagement } & 350 & SE1-Helping students to think critically & $7.15 \pm 0.69$ \\
\hline & & $\begin{array}{l}\text { SE2-Motivating students who show low interest in scientific } \\
\text { inquiry }\end{array}$ & $6.52 \pm 0.71$ \\
\hline & & $\begin{array}{l}\text { SE3-Getting students to believe they can do well in scientific } \\
\text { inquiry }\end{array}$ & $7.07 \pm 0.71$ \\
\hline & & SE4-Helping students value learning through scientific inquiry & $7.27 \pm 0.69$ \\
\hline & & SE5-Fostering student creativity & $6.93 \pm 0.69$ \\
\hline & & $\begin{array}{l}\text { SE6-Improving understanding of a student who is failing in } \\
\text { scientific inquiry }\end{array}$ & $6.57 \pm 0.72$ \\
\hline \multirow[t]{7}{*}{ Classroom management } & 350 & $\begin{array}{l}\text { CM1-Making teacher's expectations clear about student } \\
\text { behavior }\end{array}$ & $7.22 \pm 0.70$ \\
\hline & & CM2-Establishing routines to keep activities running smoothly & $7.27 \pm 0.73$ \\
\hline & & CM3-Getting students to follow classroom rules & $7.56 \pm 0.66$ \\
\hline & & CM4-Calming a student who is disruptive or noisy & $7.51 \pm 0.71$ \\
\hline & & $\begin{array}{l}\text { CM5-Establishing a classroom management system with } \\
\text { groups of students in scientific inquiry activities }\end{array}$ & $7.58 \pm 0.70$ \\
\hline & & $\begin{array}{l}\text { CM6-Keeping a few problem students from running an entire } \\
\text { lesson }\end{array}$ & $7.51 \pm 0.74$ \\
\hline & & CM7-Responding to defiant students & $7.65 \pm 0.73$ \\
\hline \multirow[t]{7}{*}{ Instructional strategies } & 350 & $\begin{array}{l}\text { IS1-Responding difficult questions in scientific inquiry from } \\
\text { students }\end{array}$ & $7.56 \pm 0.65$ \\
\hline & & $\begin{array}{l}\text { IS2-Gauging (assessing) student's comprehension in scientific } \\
\text { inquiry what teacher has taught }\end{array}$ & $7.22 \pm 0.70$ \\
\hline & & IS3-Crafting good questions for scientific inquiry for students & $7.38 \pm 0.71$ \\
\hline & & $\begin{array}{l}\text { IS4-Using a variety of assessment strategies for assessing } \\
\text { scientific inquiry }\end{array}$ & $7.07 \pm 0.71$ \\
\hline & & $\begin{array}{l}\text { IS5 - Providing an alternative explanation, for example, when } \\
\text { students are confused in scientific inquiry }\end{array}$ & $7.56 \pm 0.66$ \\
\hline & & $\begin{array}{l}\text { IS6-Implementing alternative strategies for scientific inquiry } \\
\text { in the classroom }\end{array}$ & $7.07 \pm 0.61$ \\
\hline & & $\begin{array}{l}\text { IS7-Providing appropriate challenges for very capable } \\
\text { students in scientific inquiry }\end{array}$ & $7.58 \pm 0.71$ \\
\hline
\end{tabular}




\section{Perceived TSEIS}

According to Table 3, it is notable that teachers' self-reported efficacy beliefs in IS of scientific inquiry were at a satisfactory level, particularly with diverse groups of students, for example, those confused in scientific inquiry $(7.56 \pm 0.66)$ as well as those who were capable in scientific inquiry $(7.58 \pm 0.71)$. In addition, the participating teachers held quite a high belief that they could respond to difficult questions in scientific inquiry from students $(7.56 \pm 0.65)$. On the other hand, the results showed relatively low sense of belief in applying alternative strategies for scientific inquiry in the classroom $(7.07 \pm 0.61)$ as well in using a variety of assessment strategies for assessing scientific inquiry $(7.07 \pm 0.71)$. This would be a notable fact in constructive alignment in teaching scientific inquiry.

The mean score of around 7 suggested that there was a moderately high self-efficacy in overall beliefs in IS associated with scientific inquiry in science. The majority (more than $50 \%$ ) of science teachers noted quite a high belief that they could perform the IS of responding, assessing, and providing an alternative explanation for both students who were confused as well as those very capable in scientific inquiry in teaching scientific inquiry.

\section{PD Program Toward Scientific Inquiry}

The perceived support from PD programs toward scientific inquiry was investigated in terms of efficacy sources of social cognitive theory and results are shown in Table 4.

Table 4 showed that use of enactive mastery experiences engaging long-term inquiry-based research projects $(2.60$ \pm 1.09 ) and enactive mastery teaching experiences during student teaching/induction year (3.14 \pm 1.18$)$ in PD programs which could develop science teachers' self-efficacy for teaching scientific inquiry was comparatively lower than that of using vicarious experiences. It was notable that use of vicarious experiences through modeling specific set of professional behaviors of scientific inquiry teaching (3.33 \pm 1.13 ) was moderately high in science PD programs. On the other hand, it reported relatively high use of PD programs allowing verbal persuasion such as collaborative training techniques that draw on the features of small group interactions $(3.39 \pm 1.11)$. At the same time, it was evident that during PD programs for scientific inquiry, science teachers had been guided by less experienced teacher educators with less confidence and less competence as a science educator, which led to weaken self-efficacy beliefs through negative appraisals than to strengthen such beliefs.

\section{Predictors of Self-efficacy in Student Engagement for Inquiry-based Science Teaching}

A (GLM univariate) procedure was used to test association among school characteristics (school type and education zone in which the school is situated), two subscales of self-efficacy $(\mathrm{CM})$ and IS in teaching scientific inquiry) and self-efficacy in student engagement in scientific inquiry. The GLM procedure resulted (Table 4, model) except the education zone; all other variables were positively associated with science teachers' self-reported efficacy in student engagement for scientific inquiry in secondary classes (Grade 6-13). Among the tested variables, only school type, TSECM, self-efficacy in IS, and perceived support from PD programs reported as significant predictors of TSESE with regard to scientific inquiry teaching. The results of GLM are shown in Table 5.

When an insignificant variable of education zone was removed, it found school type, TSECM, self-efficacy in IS, and perceived support from PD programs as significant predictors of TSESE, indicating that there was a positive relationship among these four variables and the self-efficacy in student engagement. The R square value was 0.345 , which means $34.5 \%$ of the variation in self-reported mean self-efficacy level in student engagement for scientific inquiry could be explained by school type, TSECM, self-efficacy in IS, and perceived support from PD programs.

The relationship between school type and self-reported mean self-efficacy level in student engagement for scientific inquiry differed across measures. The results also showed the mean self-reported efficacy in student engagement differ significantly for two pairs of type of schools; between type $1 \mathrm{AB}$ and type 3 $\left(\mathrm{r}^{2}=0.293, \rho=<0.001\right)$ and between type $1 \mathrm{C}$ and type $3\left(\mathrm{r}^{2}=\right.$ $0.246, \rho=0.004)$. The mean perceived efficacy in student engagement among science teachers in type $1 \mathrm{AB}$ and also in type $1 \mathrm{C}$ was significantly higher compared to that of those in type 3 schools.

\begin{tabular}{|c|c|c|c|}
\hline Self-efficacy sources & $\mathbf{n}$ & Factors & Mean \pm standard deviation(1-5) \\
\hline \multirow[t]{3}{*}{ Enactive mastery experiences } & 350 & TEP1-Engaging long-term inquiry based research projects & $2.60 \pm 1.09$ \\
\hline & & $\begin{array}{l}\text { TEP2-Employing (enactive mastery) teaching experiences during student } \\
\text { teaching/induction year }\end{array}$ & $3.14 \pm 1.18$ \\
\hline & & TEP3-Simulated lessons with feedback & $2.29 \pm 1.17$ \\
\hline Vicarious experiences & 350 & $\begin{array}{l}\text { TEP4-Modeling specific set of professional behaviors of scientific inquiry } \\
\text { teaching }\end{array}$ & $3.33 \pm 1.13$ \\
\hline \multirow[t]{3}{*}{ Social/verbal persuasion } & 350 & $\begin{array}{l}\text { TEP5-Collaborative training techniques that draw on the features of small } \\
\text { group interaction }\end{array}$ & $3.39 \pm 1.11$ \\
\hline & & $\begin{array}{l}\text { TEP6-Guiding science teachers by less experienced teacher educators with } \\
\text { less confidence and less competent as a science educator }\end{array}$ & $3.00 \pm 1.24$ \\
\hline & & Prepared with adequate length of training session & $3.30 \pm 1.07$ \\
\hline
\end{tabular}




\begin{tabular}{|c|c|c|c|c|c|}
\hline Variable & Mean \pm standard error (1-9) & B & p-value & Conclusion & Comparison \\
\hline Education zone & & & 0.627 & Not Sig. diff. & $\mathrm{H}>\mathrm{C}$ \\
\hline Colombo & $6.55 \pm 0.04$ & & & & \\
\hline Homagama & $6.59 \pm 0.04$ & & & & \\
\hline School type & & & $<0.001$ & Sig. diff. & $1 \mathrm{AB}>1 \mathrm{C}>\mathrm{T} 3$ \\
\hline Type $1 \mathrm{AB}$ & $6.77 \pm 0.03$ & & & & \\
\hline Type $1 \mathrm{C}$ & $6.70 \pm 0.06$ & & & & \\
\hline Type 3 & $6.25 \pm 0.06$ & & & & \\
\hline TSECM & & 0.209 & $<0.001$ & Sig. diff & \\
\hline TSEIS & & 0.406 & $<0.001$ & Sig. diff. & \\
\hline TEP & & 0.070 & 0.002 & Sig. diff. & \\
\hline
\end{tabular}

TSECM: Teacher self-efficacy in classroom management, TSEIS: Teacher self-efficacy in instructional strategies

Among the teacher efficacy related subscales, the positive interaction would imply that teachers' perceived self-efficacy in $\mathrm{CM}\left(\mathrm{r}^{2}=0.209, \rho=<0.001\right)$ and in IS $\left(\mathrm{r}^{2}=0.406, \rho=<0.001\right)$ were likely to have an impact on increasing perceived selfefficacy in student engagement of scientific inquiry. The results further revealed that the impact of perceived self-efficacy in IS on that of student engagement for the scientific inquiry was higher than that of CM. Similarly, teachers' perceived support from PD programs toward scientific inquiry teaching in science reported having a slight catalytic effect on their increased perceived self-efficacy in student engagement of scientific inquiry in the classroom $\left(r^{2}=0.070, \rho=0.002\right)$.

\section{DISCUSSION}

Despite the emphasis laid on inquiry-based science instruction in producing scientifically literate citizens in most of the recent science education reform documents (AAAS, 1993; NRC, 1996, 2000), its enactment in the science classroom is still a potentially fruitful area for further research. Teachers' selfefficacy as a critical factor in teacher performance in scientific inquiry has not amply researched in the Sri Lankan context. This study has important implications in filling this research gap. The outcomes of this study indicate teachers' perceived self-efficacy, support from science teacher PD programs, and the impact of school-related and teachers' efficacy related predictors on their self-reported efficacy in student engagement in relation to enactment of inquiry-based instruction in science classrooms.

The research sought to describe the changes in self-reported mean TSE in teaching scientific inquiry, in general, as well in terms of student engagement, CM, and IS. Although the reported overall self-efficacy was quite high $(7.24 \pm 0.44)$, the levels differed across subscales. In compliance with previous studies (Roberts et al., 2006; Seneviratne et al., 2018; Seneviratne, 2018; Seneviratne et al., 2019a; Stripling et al., 2008; Swan et al., 2011; Wolf et al., 2008), this investigation also found relatively a lower level of efficacy beliefs in student engagement domain compared to other two domains. On the other hand, other studies showed contradictory findings in this regard (Ahokoski et al., 2017; Silm et al., 2017) revealed that teachers had experienced an increase particularly in their efficacy for student engagement related to inquiry learning. Ahokoski et al. (2017) elaborate that this change might be due to the fact that those teachers were able to directly observe students' engagement and enthusiasm while working on an inquiry activity in a training course, which then immediately influenced their confidence on the matter. Silm et al. (2017) also experienced the same fact behind this increase in efficacy in student engagement "it may be that the teachers had positive experiences with IBL, which in turn impacted their general belief on how well they can engage students" (p. 323). This study provides an important insight identifying some underlying factors affecting self-efficacy in student engagement. However, this mixed result of changes in self-efficacy in student engagement along with the underlying reasons for such changes compared to self-efficacy in CM and IS need to be further supported from future research.

Apart from self-efficacy changes, this study also investigated NOS teacher PD programs, in particular, it's tailoring to use self-efficacy sources (as defined by Bandura, 1994) to support science teachers for implementing inquiry-based science instruction in the classroom. The findings showed that the commonly employed source of efficacy in PD programs was $\mathrm{verbal} /$ social persuasion (collaborative training techniques that draw on the features of small group interaction). Furthermore, the results revealed a moderate level of use of modeling specific set of professional behaviors of scientific inquiry teaching which has been categorized as powerful vicarious experiences in raising self-efficacy beliefs. The other notable fact was less use of PD programs with enactive mastery experiences, which allows science teachers authentic experiences of scientific inquiry practices. If teachers have more opportunities for mastery experiences such as scientific inquiry projects (Liang \& Richardson, 2009), simulated lessons and successful participation in science teaching practice (Kenny et al., 2014; Mansfield \& Woods-McConney, 2012), the higher chance is that they will use it in their teachings (Magee \& Flessner, 2012; Morrison, 2014). Designing PD programs of such kinds would benefit science teachers as they would then have multiple opportunities to develop their understanding of science and 
scientific inquiry (Lee \& Shea, 2016; Liang \& Richardson, 2009 ) and, therefore, would be more likely to develop more positive attitudes and become more confident and effective in teaching inquiry-based science to their students. In addition, the finding about science teachers being guided by mentors those who were less experienced, with less confidence and less competent as a science educator need to be taken into consider if it requires strengthening teachers' beliefs toward inquiry teaching through positive appraisals.

The third objective of the study was to determine the predictors of self-efficacy in student engagement in scientific inquiry. Among the tested variables, school type, perceived support from PD programs, and two sub scales of self-efficacy (TSECM and TSEIS) reported as significant predictors. The findings related to underlying causes for teachers' being less confident in engaging student in IBL would benefit teacher educators in assisting science teachers through appropriate PD programs. The significant impact of the efficacy in IS on efficacy belief of student engagement would provide valuable insights on how PD programs need to be tailored to teachers' beliefs and actual practices. In addition, the study findings stressed that perceived efficacy beliefs in engaging students in scientific inquiry among teachers in type three schools (with grades from 1 to 8 ) were significantly low. This fact is of uttermost important which needs immediate interventions through SBTD programs currently emphasized in teacher education in Sri Lanka. The fact that effect of access to laboratory resources on the kinds of science instruction taught in high poverty schools highlighted by Smith et al. in 2007 carrying out a similar study would pave an important path in remedying this problem. Furthermore, the study revealed how perceived support from PD programs significantly impact on science teachers' efficacy belief in student engagement. Previous studies (Ahokoski et al., 2017; Liang \& Richardson, 2009; Palmer et al., 2015; Seneviratne et al., 2019b; Swan et al., 2011) found in line with this aspect. The authors in these studies have discussed in detail how teachers' efficacy beliefs have been strengthened through multi-faceted forms of PD programs. PD through science methods courses have often been positive in enhancing self-efficacy (Palmer et al., 2015). Palmer et al. suggest that even commonly employed traditional science content courses can be successful in building selfefficacy if they are tailored to the needs of students and also are taught be enthusiastic teacher educators who are willing to utilize a wide range of teaching techniques that enhance learning (p. 38). Silm et al. in 2017 experienced a positive effect of a specially designed model of teacher training with three phases (teachers as learners, thinkers, and reflective practitioners) student engagement sub scale of teacher efficacy. It is recommended that teacher educators in Sri Lanka should focus on such teacher development interventions to assist teachers to try out inquiry approach within their classrooms.

This study has some limitations that should be addressed in the future research. One limitation is that the results being based solely on self-reported data. Follow-up studies employing various other data gathering instruments, more specifically, classroom observations and interviews would result higher reliability and validity of self-reported data. These options would require more extensive resources and capacities of the researcher. Even if such resources were available, getting consent of the principals and teachers for classroom observation and getting student perspectives on their teachers' use of instructional practices is not a guarantee, according to the ethical considerations of schools in Colombo district. The support of the administrative officers at Ministry of Education as well provincial Education offices in the country is vital.

Carrying out the study as a cross-sectional study was another limitation. The results would likely have been more valid and reliable if data would be obtained implementing the research as a longitudinal study. The relationship between self-efficacy and professional support through teacher training courses would not completely revealed without gathering data during actual implementation phase in the classrooms.

\section{CONCLUSION}

Although science teachers are envisioned to play a key role in implementing authentic scientific inquiry in the classrooms, designing PD programs, which ensure effective training transfer through self-efficacy sources are lacking in Sri Lanka as in many other countries. Hence, effectiveness of designs of $\mathrm{PD}$ that ensure science teachers more opportunities to enhance efficacy beliefs toward authentic scientific inquiry are still a potential area for research in science education context.

This study provides valuable insights into the science teachers' efficacy beliefs in engaging students in scientific inquiry and how other efficacy beliefs, perceived support from PD programs and school characteristics related to these beliefs. However, further research would benefit from improved scale of measuring TSE to determine the other technical, political, and cultural barriers in line with enacted type of inquiry science in the classroom.

\section{REFERENCES}

Abd-El-Khalick, F., BouJaoude, S., Hofstein, A., Lederman, N.G., Mamlock, R., Niaz, M.,Treagust, D., \& Tuan, H. (2001). Inquiry in Science Education: International Perspectives. St. Louis, MI: An ICASE Symposium Conducted at the Annual Meeting of the National Association for Research in ScienceTeaching.

Ahokoski, E., Korventausta, M., Veermans, K., \& Jaakkla, T. (2017). Teachers' experiences of an inquiry learning training course in Finland. Journal of science Education, 28(4), 305-314.

Almuntasheri, S., Gillies, R.M., \& Wright, T. (2016). The effectiveness of a guided inquiry-based, teachers' professional development programme on Saudi students' understanding of Density. Science Education Journal, 27(1), 16-39.

American Association for the Advancement of Science (AAAS). (1993). Benchmarks for Science Literacy. New York: Oxford University Press.

Anderson, R.D. (2002). Reforming science teaching: What research says about inquiry? Journal of Science Teacher Education, 13(1), 1-12.

Appleton, K., \& Kindt, I. (2002). Beginning elementary teachers' development as teachers of science. Journal of Science Teacher Education, 13(1), 43-61.

Bandura, A. (1986). Social Foundations of thought and Action a Social Cognitive Theory. Englewood Cliffs, NJ: Prentice-Hall. 
Bandura, A. (1994). Self-efficacy. In: Corsini, R.J. (Ed.), Encyclopedia of Psychology. $2^{\text {nd }}$ ed., Vol. 3. New York: Wiley. p368-369.

Bandura, A. (1997). Self-efficacy the Exercise of Control. Englewood Cliffs, NJ: Prentice-Hall.

Bryan, L.A., \& Atwater, M.M. (2002). Teacher beliefs and cultural models: A challenge for science teacher preparation programs. Science Education, 86, 821-839.

Capps, D.K., \& Crawford, B.A. (2013). Inquiry-based professional development: What does it take to support teachers in learning about inquiry and nature of science? International Journal of Science Education, 35(12), 1947-1978.

Choi, S., \& Ramsey, J. (2009). Constructing elementary teachers' beliefs, attitudes, and practical knowledge through an inquiry-based elementary science course. School Science and Mathematics, 109(6), 313-324.

Crawford, B.A. (2000). Embracing the essence of inquiry: New roles of the science teacher, Journal of Research in Science Teaching, 37(9), 916-937.

Decoito, I., \& Myszkal, P. (2018). Connecting science instruction and teachers' self-efficacy and beliefs in STEM education. Journal of Science Teacher Education, 29(3), 485-503.

Erticanto, C., Yunarti, T., \& Saputra, A. (2017). Development and evaluation of a model-supported scientific inquiry training programme for elementary teachers in Indonesia. International Journal of Instruction, 10(3), 93-108.

Gunawardane, R. (2011). A Study on the Effectiveness of Short-term inservice Teacher Training in the Teaching Learning Process. Sri Lanka: National Education Commission.

Gunning, A.M., \& Menash, F.M. (2011). Pre-service primary teachers' development of selfefficacy and confidence to teach science: A case study. Journal of Science Teacher Education, 22, 171-185.

Guskey, T.R. (1988). Teacher efficacy, self-concept, and attitudes toward the implementation of instructional innovation. Teaching and Teacher Education: An International Journal of Research and Studies, 4(1), 63-69.

Holtzberger, D., Philipp, A., \& Kunter, M. (2013). How teachers' selfefficacy is related to instructional quality: A longitudinal analysis. Journal of Educational Psychology, 105(3), 774-786.

Jeanpierre, B., Oberhauser, K., \& Freeman, C. (2005). Characteristics of professional development that effect change in secondary science teachers' classroom practices. Journal of Research in Science Teaching, 42(6), 668-690.

Kennedy, M. (1998). Form and Substance in in-service Teacher Education (Research Monograph No.3). Madison, WI: National Institute for Science Education.

Kenny, J.D., Hobbs, L., Herbert, S., Jones, M. Chittleborough, G., Campbell, A., \& Redman, C. (2014). Science Teacher Education Partnerships (STEPS) in science teacher education. Australian Journal of Teacher Education, 39(12), 43-65.

Klassen, R.M., \& Tze, V.M. (2014). Teachers' self-efficacy, personality, and teaching effectiveness: A meta-analysis. Educational Research Review, 12, 59-76.

Lee, C.K., \& Shea, M. (2016). An analysis of pre-service elementary teachers' understandings of inquiry-based science teaching. International Journal of Science Education, 27(2), 219-237.

Lee, O., Hart, J.E., Cuevas, P., \& Enders, C. (2004). Professional development in inquiry-based science for elementary teachers of diverse student groups. Journal of Research in Science Teaching, 41(10), 1021-1043.

Leonard, J., Barner-Jihnson, J., Dantly, S.J., \& Kimber, C. (2011). Teaching science inquiry in urban contexts: The role of elementary pre-service teachers' beliefs. The Urban Review, 43, 124-150.

Lewthwaite, B. (2006). I want to enable teachers in their change: Exploring the role of a superintendent on science curriculum delivery. Canadian Journal of Educational Administration and Policy, 52, 1-24.

Liang, L.L., \& Richardson, G.M. (2009). Enhancing prospective teachers' science teaching efficacy beliefs through scaffolded, student-directed inquiry. Journal of Elementary Science Education, 21(1), 51-66.

Lotter, C., Harwood, W.S., \& Bonner, J.J. (2007). The influence of core teaching conceptions on teachers' use of inquiry teaching practices. Journal of Research in Teaching Science, 44(9), 1318-1347.

Lotter, C.R., Thompson, S., Dickenson, T.S., Smiley, W.F., Blue, G., \& Rea, M. (2018). The impact of practice-teaching professional development model on teachers' inquiry instruction and inquiry efficacy beliefs. International Journal of Science and Mathematics Education, 16(2), 255-273.

Magee, P., \& Flessner, R. (2012). Collaborating to improve inquiry based teaching in elementary science and mathematics methods course. Science Education International, 23(4), 353-365.

Mansfield, C.F., \& Woods-McConney, A. (2012). I didn't always perceive myself as a "science person": Examining efficacy for primary science teaching. Journal of Primary Science Education, 37(10), 37-52.

McCaul, T. (2007). Study of the Implementation of Mathematics and Science Curriculum in Grade 6 and 10: Finalreport. Colombo: World Bank. Available from: http://www.sooperarticles.com/education-articles/ tutoring-articles/effectiveteachers-teachingwhat-principals-needknow-impact-student-achievement-398093.html. [Last accessed on 2017 Jul 25].

Mintzes, J.B., Marcum, B., Messerschmidt-Yates, C., \& Mark, A. (2013). Enhancing self-efficacy in elementary science teaching with professional learning communities. Journal Science Teacher Education, 24(7), 1202-1218.

Morrison, J.A. (2014). Scientists' participation in teacher professional development: The impact on fourth to eighth grade teachers' understanding and implementation of inquiry science. International Journal of Science and Mathematics Education, 12(4), 793-816.

National Research Council (NRC). (1996). National Science Education Standards. Washington, DC: National Academy Press.

National Research Council (NRC). (2000). Inquiry and the National Science Education Standards: A Guide for Teaching and Learning. Washington, DC: National Academy Press.

Palmer, D., Dixon, J., \& Archer, J. (2015). Changes in science teaching self efficacy among primary teacher education students. Australian Journal of Teacher Education, 40(12), 27-40.

Posnanski, T.J. (2007). A redesigned Geoscience content course's impact on science teaching selfefficacy beliefs. Journal of Geoscience Education, $55(2), 152-157$.

Ramnarain, U. (2016). Understanding the influence of intrinsic and extrinsic factors on inquirybased science education at township schools in South Africa. Journal of Research in Science Teaching, 53(4), 598-619.

Rice, D.C., \& Roychoudhury, A. (2003). Preparing more confident pre-service elementary science teachers: One elementary science methods teacher's self-study. Journal of Science Teacher Education, 14(2), 97-126.

Roberts, T.G., Harlin, J.F., \& Briers, G.E. (2006). A longitudinal examination of teaching efficacy of agricultural science students teachers. Journal of Agricultural Education, 47(2), 81-92.

Sandholtz, J.H., \& Ringstaff, C. (2013). Assessing the impact of teacher development on science instruction in the early elementary grades in rural US schools. Professional Development in Education, 39(5), 678-697.

Seneviratne, D.V.K. (2009). An Inquiry into the Organization of Lessons Towards the Intended Outcomes of the Science Curriculum of 2007 at the Junior Secondary Level in the Schools of Sri Lanka (In Relation to Sri Jayewardenepura Education Zone). Unpublished Masters Thesis. Colombo: University of Colombo.

Seneviratne, D.V.K. (2018). Teaching Science as Inquiry: The Role of Novice vs. Experienced Teachers'Self-efficacy. A Paper Presented at the Annual Research Symposium, Faculty of Education. Sri Lanka: University of Colombo.

Seneviratne, D.V.K., Khatibi, A., \& Azam, S.M.F. (2018). Changes in Practicing Teachers' Self-efficacy in Teaching Scientific Inquiry. Bangkok, Thailand: Paper Presented at the $15^{\text {th }}$ Annual World Congress of Academy for Global Business Advancement (AGBA) on Business and Entrepreneurship Development in a Globalized and Digitalized Era.

Seneviratne, K., Hamid, J.A., Khatibi, A., Azam, F., \& Sudasinghe, S. (2019a). In-service science teachers' self-efficacy in teaching scientific inquiry: A case in Sri Lanka. International Journal of Recent Scientific Research, 10(08), 34423-34430.

Seneviratne, K., Hamid, J.A., Khatibi, A., Azam, F., \& Sudasinghe, S. (2019b). Multi-facetedprofessional development designs for science teachers' self-efficacy for inquiry-based teaching: A critical review. Universal Journal of Educational Research, 7(7), 1595-1611.

Silm, G., Tiitsaar, K., Pedaste, M., Zacharia, Z.C., \& Papaevripidou, M. (2017). Teachers' readiness to use inquiry-learning: An investigation of 
teachers 'sense of efficacy and attitudes toward inquiry-based learning. Science Education Journal, 28(4), 315-325.

Smolleck, L.A., \& Mongan, A.M. (2011). Changes in pre-service teachers; self-efficacy: From science methods to student teaching. Journal of Educational and Developmental Psychology, 1, 133-145.

Stripling, C., Ricketts, J.C., Roberts, T.G. \& Harlin, J.F. (2008). Pre-service agriculture education teachers' sense of teaching self-efficacy. Journal of Agricultural Education, 49(4), 120-130.

Swan, B.G., Wolf, K.J., \& Cano, J. (2011). Changes in teacher self-efficacy from the student teaching experience through the third year of teaching. Journal of Agricultural Education, 52(2), 128-139.

Swars, S.L., \& Dooley, C.M. (2010). Changes in teaching efficacy during a professional development school-based science methods course. School Science and Mathematics, 110, 193-202.

Tschannen-Moran, M., \& Woolfolk, H.A. (2001). Teacher efficacy: Capturing an elusive construct. Teaching and Teacher Education, 17, 783-805.
Tschannen-Moran, M., Woolfolk Hoy, A., \& Woolfolk Hoy, K. (1998). Teacher efficacy: Its meaning and measure. Review of Educational Research, 68(2), 202-248.

Voet, M., \& De Wever, B. (2017). Preparing pre-service history teachers for organizing inquirybased learning: The effects of an introductory training programme. Teacher and Teacher Education, 63, 206-217.

Wolf, K.J., Foster, D.D., \& Berkenholz, R.J. (2008). Changes in Teacher Self-efficacy and Perceptions of Preparation of Agricultural Education Teacher Candidates. Cornell, New York: Proceedings of the North Central AAAE Conference. p180-191. Available from: http://www. aaaeonline.org/allconferences.php?show_what=NorthCentral. [Last accessed on 2018 Sep 25].

Zimmerman, W.A., Knight, S.L., Favre, D.E., \& Ikhlef, A. (2017). Effect of professional development on teaching behaviors and efficacy in Qatari educational reforms. Teacher Development, 21(2), 324-345. 